\title{
HUKUM ISLAM DI MATA ORIENTALIS Formulasi Hukum Islam dalam Perspektif Joseph Schacht
}

Kholil Syu'aib

\begin{abstract}
Joseph Schacht is very famous Western scholar in the field of Islamic law. Along of his life time, he devoted himself to historical study of thoughts of Islamic law since its early periods. In his works, he elaborates historical outline and growth of the thoughts of Islamic law by using modern approach and methodologies. Schacht ideas concerning formation of Islamic law brought about discussion and debate especially among masters of Islamic law, so that they are inspired to research it.
\end{abstract}

Key words: Islamic law, history, and orientalis

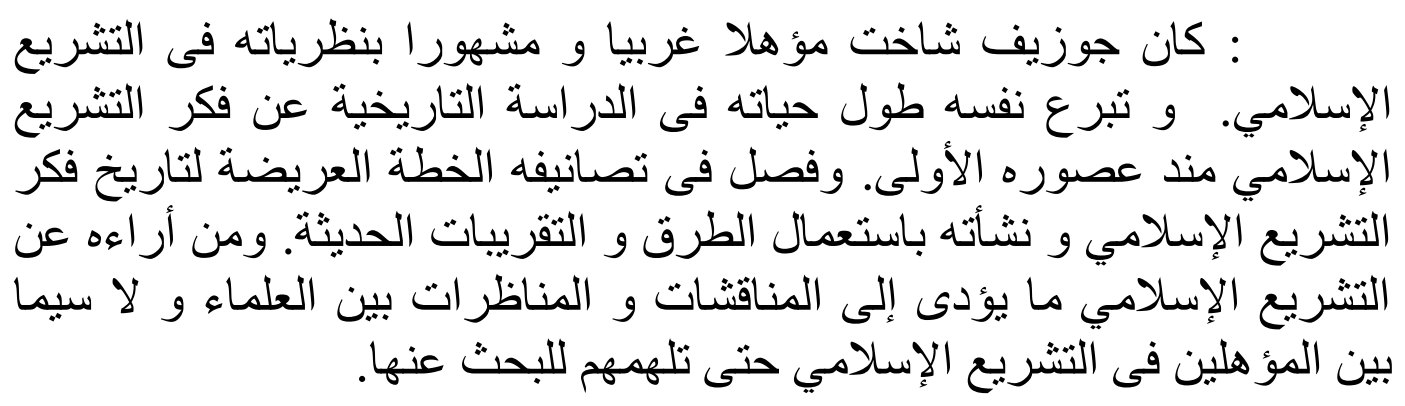

\section{Pendahuluan}

Sebagai seorang sejarawan hukum, Schacht telah memberikan sumbangan yang berarti bagi pengetahuan kita khususnya perkembangan sejarah hukum Islam. Schacht tentunya tidak berlebihan mengatakan bahwa hukum Islam menempati posisi sentral dalam rasa keagamaan kaum muslimin. ${ }^{1}$ Bahkan sekarangpun, ketika pengaruh nilai-nilai Barat sedemikian dalamnya merasuki jiwa tatanan masyarakat muslim, hukum Islam masih terbukti mampu memainkan peran yang begitu menentukan dalam kancah pergulatan antara kelompok tradisionalis dan modernis yang muncul dalam peradaban Islam itu sendiri. Schacht sendiripun sesungguhnya telah lama mengemukakan tesisnya bahwa seorang pemerhati peradaban Islam tidak akan mampu memahami gejolak perkembangan lembaga hukum Islam di negara-negara muslim modern sekarang ini tanpa adanya pemahaman yang mendalam tentang sejarah teori dan praksis hukum positif dalam Islam. ${ }^{2}$

Gagasan Schacht mengenai perkembangan historis hukum Islam telah menghasilkan suatu kesimpulan yang diperdebatkan serius di antara para pengkaji Islam. Sebagian di antara mereka secara umum menerima gagasan itu, tetapi mengkritik aspek-aspek tertentu dari pendapat itu, sementara sebagian yang lain dengan keras menentangnya. Bagaimanapun tanggapan mereka, pemikiran Schacht tetap merupakan suatu keberhasilan yang besar di bidang hukum Islam. Gagasan itu telah memberi inspirasi kepada para pengkaji Islam dalam penelitian mereka tentang persoalan tersebut. Karya besarnya, The Origins 
of Muhammadan Jurisprudene dan An Introduction to Islamic Law, di mana ia mengelaborasi sebagian besar gagasannya secara spektakuler.

\section{Biografi Singkat Joseph Schacht}

Walaupun bukan bermaksud menulis biografi Schacht secara detail, dalam hal ini diupayakan memberikan garis besar peristiwa-peristiwa tertentu yang berarti dalam karirnya dan lebih berkonsentrasi pada faktor-faktor yang perlu bagi pemahaman kita tentang latar belakangnya sebagai sarjana dalam kajian keislaman, khususnya hukum Islam.

Schacht lahir pada tanggal 15 Maret 1902 di Ritabor, Silesia yang dulu di wilayah Jerman dan sekarang termasuk Polandia (Rociborz), hanya menyeberangi perbatasan dari Cekoslowakia. ${ }^{3}$ Di kota ini, ia tumbuh berkembang dan tinggal selama delapan belas tahun pertama dari kehidupannya. ${ }^{4}$

Schacht berhasil memperoleh tingkat pendidikan tinggi. Ia memulai pendidikannya di kota kelahirannya, Ritabor. Setelah mempelajari bahasa Yahudi dari seorang rabbi dan berhasil menguasainya, kemudian ia menerima pendidikan Gymnasium Klasikal di sana (1911-1920), setelah itu ia melanjutkan studinya ke Universitas Breslau (Wroclaw) dan Leipzig, di mana pertama kali ia mengkaji filologi klasik, semitik dan juga teologi. ${ }^{5}$

Pada tahun 1922, ia mendapat penghargaan (accountability) dengan memenangkan medali universitas dengan satu risalah tentang Perjanjian Lama dan ia memperoleh gelar D.Phil dengan predikat Summa Cumlaude dari Universitas Breslau pada akhir tahun 1923. Ia juga mendapatkan gelar M.A. pada tahun 1947 dan gelar D.Litt. pada tahun 1952, keduanya dari Universitas Oxford. ${ }^{6}$ Disertasi doktornya terdiri dari sebuah edisi dengan terjemahan dan komentar atas Kitab al-Hiyal wa al-Makharij karya Khassaf (Hanover, 1923), sebuah teks Arab abad pertengahan tentang perlengkapan hukum.

Pendidikan teoritis Schacht tidak terpisahkan dari aspek-aspek praktis topikal dari bidang studinya. Selama periode jabatan akademisnya yang pertama di Universitas Freiburg Breisgau pada tahun 1925, ia mengambil keuntungan dari hubungan dengan kawan-kawannya di fakultas hukum. Dengan demikian, tanpa mengambil gelar hukum ia mendapatkan dasar pengetahuan teknis yang cukup untuk mendukung karir penelitiannya tentang hukum Islam dengan bacaan dan pergaulannya sendiri. ${ }^{7}$

Pada tahun 1939, Schacht pindah ke Inggris. Ia bekerja sebagai ahli dan peneliti masalah-masalah ketimuran di Departemen Penerangan Inggris. ${ }^{8}$ Pada tahun 1946, ia pertama kali dipilih sebagai dosen di Universitas Oxford, lalu belakangan sebagai analis di bidang kajian-kajian keislaman, terutama hukum Islam. Selama beberapa tahun di Oxford, ia mampu menyelesaikan karyanya, The Origins. ${ }^{9}$

Penelitiannya di Afrika sangat bermakna bagi karirnya, karena ia mempunyai kesempatan kontak dengan kehidupan nyata masyarakat muslim yang hasilnya tiba-tiba menjadi terwujud dalam pengujiannya yang mendalam terhadap masjid-masjid sektarian (An Unknown Type of Minbar and Its Historical 
Significance, 1957). ${ }^{10}$ Lebih khusus, ia menjadi lebih akrab dengan problematika penerapan hukum Islam dalam konteks sosial. ${ }^{11}$

Pada tahun 1954, setelah meninggalkan jabatannya di Oxford, dengan berat hati Schacht meninggalkan Inggris ke Belanda untuk menduduki guru besar di bidang bahasa Arab di Universitas Leiden. Di sini ia mampu mengkaji secara intensif di bawah bimbingan C. Snouck Hurgronje. ${ }^{12}$

Pada tanggal 1 Agustus 1969, Schacht meninggal dunia di rumah di New Jersey, karena terserang pendarahan otak. Sebelum meninggal, ia pernah merencanakan untuk melengkapi beberapa edisi dan studi tentang Kitab alTauhid karya al-Maturidi dan Mudawwanah karya Sahnun. Sayangnya, proyek ini tidak dapat direalisasikan. ${ }^{13}$

Ada beberapa karya yang ditulis Schacht tentang hukum Islam, meski demikian, sebagian besar gagasan utamanya diungkapkan dalam karyanya, The Origins, dan secara ringkas dijelaskan kembali dalam karyanya, An Introduction. Kedua karyanya itu memiliki semua sifat keaslian dan pemikiran yang mendalam. Kedua karyanya itu telah mendorong sejumlah sarjana untuk melakukan penelitian lebih jauh.

\section{Pembentukan Hukum Islam}

Perkembangan historis sumber-sumber hukum Islam dan peran sentral dalam pembentukannya merupakan perhatian utama Schacht. Schacht berpendapat, Syafi'i adalah orang yang bertanggung jawab atas perkembangan teori tentang empat sumber pokok hukum Islam; al-Qur`an, sunnah Nabi, ijma' dan qiyas. Schacht juga mempertahankan bahwa Syafi'i adalah orang pertama yang menyusun buku tentang teori hukum Islam, dengan berargumen bahwa pernyataan "...Abu Yusuf adalah orang pertama yang menyusun karya-karya hukum atas dasar doktrin Abu Hanifah," tidak didukung oleh sumber-sumber tertua. Oleh karena itu, tidak asing bahwa Schacht mengakui Syafi'i sebagai pendiri hukum Islam. ${ }^{14}$ Bagian ini bermaksud untuk mengemukakan pandangan-pandangan Schacht mengenai pembentukan hukum Islam, khususnya yang terkait dengan perkembangan historis sumber-sumber hukum Islam dari periode Islam yang paling awal hingga mencapai puncaknya di tangan Syafi'i.

Schacht menyatakan bahwa selama paruh awal abad pertama hijriah, hukum Islam seperti yang kita ketahui sekarang ini belum ada. ${ }^{15}$ Hukum semacam ini, Schacht mempertahankan, jatuh di luar bidang agama. Schacht berargumen, permulaan abad kedua hijriah atau periode Umayyah merupakan era di mana Islamisasi hukum bertitik tolak, yang melanjutkan perkembangannya hingga permulaan periode tulis-menulis. ${ }^{16}$ Untuk mengelaborasi gagasan ini, Schacht secara sistemantis memperhatikan perkembangan historis pemikiran hukum Islam dari periode pra-Umayyah hingga masa Syafi'i, suatu masa ketika ide tentang hukum Islam itu muncul sebagai sebuah konsep final dan lengkap.

Seharusnya diingat bahwa menurut teori hukum Islam klasik, sumbersumber pokok hukum Islam itu disusun sebagai berikut: al-Qur'an, sunnah Nabi, 
ijma' dan qiyas. Berbagai persoalan hukum yang dihadapi oleh orang-orang muslim dipecahkan dengan bantuan sumber-sumber ini secara berurutan. ${ }^{17}$ Walaupun Schacht mengakui hal ini, ia menjelaskan bahwa fakta historis merupakan unsur otoritatif terakhir dalam perumusan hukum Islam, dan bukan yang pertama. Lebih menarik lagi, Schacht berpendapat, adalah kenyataan bahwa norma-norma tertentu dari hukum Islam yang pertama berbeda dengan perkataan al-Qur`an dan eksplisit. Selain itu, ia menyatakan bahwa pusat aktivitas teorisasi dan sistemisasi pertama yang dipakai untuk mentransformasikan praktek populer dan administrasi rezim Umayyah ke dalam hukum Islam adalah Irak. Teori dan pemikiran hukum aliran-aliran Irak, menurutnya lebih dikembangkan daripada teori dan pemikiran hukum aliranaliran di tempat-tempat lainnya. ${ }^{18}$

Sesuai dengan perkembangan sunnah secara historis, Schacht menguraikan perkembangan historis sumber-sumber hukum Islam. Selama kehidupan Muhammad, menurut Schacht sunnah yang ada pada masyarakatnya merupakan salah satu sumber penting untuk memecahkan persoalan masyarakat muslim dan menjadi salah satu konsep pokok hukum Islam. ${ }^{19}$ Sunnah ini, selama periode Khulafa' Rasyidin, bercampur dengan sunnah wilayah-wilayah yang ditaklukkan di luar jazirah Arab. Konsep sunnah menjadi salah satu dari hal terpenting dalam pembentukan hukum Islam. ${ }^{20}$ Karena posisi sunnah yang signifikan itu, ayat-ayat al-Qur`an tertentu nampaknya menjadi terabaikan. ${ }^{21}$

Tahapan selanjutnya dari perkembangan itu terjadi selama periode Umayyah. Khalifah memilih qudhat (bentuk jama' dari qadhi, hakim) di masingmasing provinsi untuk memecahkan berbagai permasalahan hukum. Hukum adat masing-masing provinsi dan praktek populer serta aturan-aturan administrasi rezim Umayyah yang diinterpretasikan oleh para qadhi melalui $r a^{\prime} y$ mereka, dianggap sebagai sumber utama yang digunakan untuk menyelesaikan permasalahan-permasalahan hukum. Qudhat ini adalah pegawai-pegawai administrasi resmi rezim Umayyah dan keputusan-keputusan mereka meletakkan pondasi dasar bagi apa yang kemudian menjadi hukum Islam. ${ }^{22} \mathrm{Di}$ sini upaya-upaya teorisasi, sistemisasi, dan islamisasi pertama berawal secara serius. $^{23}$

Pada dekade pertama abad kedua, qudhat ini menjadi lebih spesialis, tertarik dengan agama dan dengan memakai pemikiran pribadi, mereka memperhatikan perluasan pandangan hidup Islam yang mencakup sistem hukum Islam. ${ }^{24}$ Sebagai akibatnya, Schacht menjelaskan praktek populer dan administrasi Umayyah periode terakhir ditransformasikan ke dalam hukum Islam. Pada tahap perkembangan berikutnya, bersama dengan para ulama yang lain, memunculkan apa yang disebut madzahib (bentuk jama' dari madzhab) yang benar-benar berbeda dengan pembagian geografis mereka. ${ }^{25}$ Aliran yang paling terkenal adalah aliran Kufah dan Bashrah di Irak, alirah Madinah Mekah di Hijaz, serta aliran Syria. ${ }^{26}$ Ijma', kesepakatan antara ulama madzahib, menjadi lebih penting daripada ra yu masing-masing ulama. Praktek masyarakat ideal yang terekspresikan dalam doktrin yang diterima para sarjana, yang dengan sederhana disebut Schacht sebagai tradisi hidup menggantikan konsep sunnah sebelumnya dan menjadi salah satu dari sumber-sumber utama hukum Islam. ${ }^{27}$ 
Karakteristik geografis aliran-aliran hukum klasik menjadi kurang didefinisikan secara tepat setelah masa Syafi'i,28 dan mereka mentrasformasikan diri ke dalam tipe aliran selanjutnya berdasarkan kesetiaan kepada guru pribadi, yang berkembang sekitar abad ketiga hijrah. Melalui berbagai perkembangan aliran Kufah klasik mentransformasikan diri ke dalam aliran Hanafiyah, ${ }^{29}$ dan aliran Madinah klasik mentransformasikan diri ke dalam aliran Malikiyah. ${ }^{30}$ Keterlibatan Syafi'i dalam proses sistemisasi dan Islamisasi hukum membantu doktrin-doktrinnya menjadi dikenal sebagai aliran Syafi'i. ${ }^{31}$ Pada tingkat tertentu, doktrin sistematis Syafi'i tidak memuaskan kelompok tertentu, khusus para ahli hadis. Berbeda dengan doktrin Syafi'i, para ahli hadis bersikap memusuhi semua pemikiran dan mencoba mempercayai hadis semata-mata ${ }^{32}$ serta mereka lebih suka kepada hadis dha'if daripada analogi (qiyas) yang kuat. Para ahli hadis mendasarkan doktrin mereka kepada seorang ahli hadis terkemuka, Ibn Hanbal ${ }^{33}$ yang kemudian diakui sebagai pendiri aliran Hanbali. ${ }^{34}$

Fenomena selanjutnya adalah munculnya sebuah gerakan keagamaan yang beroposisi terhadap kebijakan sekuler para khalifah Umayyah. Di mata gerakan keagamaan itu tindakan-tindakan dan aturan-aturan pemerintahan telah menyimpang dari ajaran agama dan upaya serius untuk memeluk doktrin secara tepat harus dilakukan. Secara luas tidak diragukan, karena alasan inilah proses Islamisasi hukum lebih dielaborasi secara sistematis. Al-Qur'an seringkali dipakai sebagai rujukan mengenai permasalahan-permasalahan hukum dan makna sunnah dibatasi secara ketat hanya kepada perkataan, perbuatan dan persetujuan (taqrir) Nabi. 35

Di tangan Syafi'i, Schacht berpendapat, sistemisasi dan Islamisasi pemikiran hukum dalam Islam telah mencapai puncaknya. ${ }^{36}$ Syafi'i menyatakan teorinya bahwa sumber-sumber hukum Islam secara hirarki adalah al-Qur`an, sunnah Nabi, ijma' dan qiyas. Seorang ulama harus menafsirkan bagian-bagian alQur'an yang bermakna ganda menurut sunnah Nabi, menurut ijma' kaum muslimin dan jika tidak ada ijma' menurut qiyas. ${ }^{37}$ Tidak ada ruangan dalam teori Syafi'i, untuk pikiran pribadi (ijtihad bi al-ra'yi) semata atau hukum kebiasaan masyarakat dalam menjelaskan berbagai keputusan hukum. ${ }^{38}$

Seperti para ulama sebelumnya, Syafi'i memposisikan al-Qur`an sebagai sumber utama hukum Islam. Sunnah ditekankan sebagai kondisi yang berhubungan dengan Nabi secara tepat. ${ }^{39}$ Ijma' para ulama, yang dipegang sebagai sumber penting bagi para pendahulunya menjadi tidak relevan bagi Syafi'i. ${ }^{40}$ Ia bahkan mengingkari keberadaan ijma' semacam itu, karena ia selalu menemukan para ulama yang memegangi pendapat-pendapat yang berbeda, ia bersandar pada ijma' seluruh umat Islam secara umum tentang persoalanpersoalan pokok. ${ }^{41}$

Sebagai sumber terakhir adalah qiyas, berbeda dengan pendapat yang lebih awal, Syafi'i pada prinsipnya hanya mengakui pemikiran analogis dan sistematis yang tepat, dengan menggunakan qiyas sebagai satu-satunya jenis pemikiran untuk menggambarkan aturan-aturan tertentu dari tiga sumber sebelumnya. ${ }^{42}$

Usaha Syafi'i ini, sebagai upaya final bagi perumusan sumber-sumber pada khususnya dan hukum Islam pada umumnya dipandang sebagai sebuah sistem konsisten yang sangat bagus dan jauh lebih unggul daripada berbagai aliranaliran klasik.43 Bagaimanapun, Schacht mengingatkan kita, usaha ini dalam 
jangka panjang hanya dapat mengarahkan kepada kekakuan dan menjadi semakin kaku serta menimbulkan cetakan finalnya.44

Sehubungan dengan hal itu, Schacht juga menyatakan, berbagai indikasi, pertama dari sebuah sikap yang mengingkari kebebasan pemikiran yang sama bagi para ulama kontemporer seperti dinikmati oleh para pendahulu mereka tampak pada tulisan Syafi'i dan sejak sekitar pertengahan abad ketiga hijrah (abad kesembilan masehi), ide itu mulai menampakkan dasar bahwa hanya para ulama besar masa lampau yang tidak dapat disamakan dan bukan epigones, memiliki hak untuk pemikiran independen (ijtihad mustaqil). Pada saat itu, istilah ijtihad telah dipisahkan dari hubungan dengan penggunaan pendapat pribadi yang bebas ( $\left.r a^{\prime} y u\right)$, dan membatasi pada penggambaran kesimpulan-kesimpulan yang benar dari al-Qur`an, sunnah Nabi, konsensus (ijma') dan dengan analogi (qiyas) atau pemikiran sistematis. ${ }^{45}$

Dalam hal-hal berikut, Schacht kelihatannya setuju dengan sebagian besar para sarjana sebelumnya, bahwa setelah Syafi'i telah terjadi peristiwa yang tidak menguntungan bagi perkembangan hukum Islam yang dikenal sebagai insidad bab al-ijtihad, tertutupnya pintu ijtihad. Pada permulaan abad keempat hijrah, pandangan pokok telah dicapai ketika para ulama dari berbagai aliran merasa bahwa pertanyaan pokok telah dikaji dan diselesaikan secara final dan sebuah konsensus telah membuat dirinya secara bertahap berakibat bahwa sejak saat itu dan selanjutnya, tak seorangpun yang mungkin dianggap memiliki kualifikasi untuk menghasilkan pemikiran independen (ijtihad mustaqil) dalam hukum Islam dan bahwa seluruh aktivitas mendatang harus dibatasi pada penjelasan, penerapan dan pada sebagian besar, penafsiran doktrin, sebagaimana ditetapkan sekali dan untuk semuanya. Tertutupnya pintu ijtihad, sebagaimana istilah itu disebut, sama dengan tuntutan untuk taqlid.46

Dalam beberapa generasi berikutnya terdapat sejumlah ulama yang berpendapat bahwa mesti selalu ada seorang mujtahid atau mesti ada orangorang yang patut dipandang memenuhi persyaratan yang sangat tinggi yang telah ditetapkan sebagai persyaratan bagi seorang mujtahid. Tetapi pandangan ini masih saja bersifat teoretis, karena tak seorangpun dari ulama yang benarbenar menghasilkan penafsiran hukum syari'ah secara independen.

Schacht mencontohkan Ibn Taimiyah, meskipun tidak secara jelas menganjurkan membuka kembali pintu ijtihad, tetapi konsekuensi dari pendapatnya tentang ijma' dia sanggup menolak taqlid, menafsirkan al-Qur`an dan hadis-hadis Nabi dengan menarik kesimpulan-kesimpulan baru mengenai berbagai kelembagaan hukum Islam. ${ }^{47}$

Apapun yang dikatakan oleh teori tentang ijtihad dan taqlid, kegiatan para ulama pada masa kemudian - setelah tertutupnya pintu ijtihad - tidak dapat dikatakan kurang kreatif daripada ulama-ulama yang lebih dahulu dari mereka.

Tentunya dari paragraf-paragraf sebelumnya jelas bahwa hukum Islam yang sampai pada permulaan pemerintahan 'Abbasiyah telah bersifat adaptif dan semenjak masa itu terus berkembang semakin kaku serta memperoleh bentuknya yang bersifat final. Memang kekakuan hukum Islam telah membantu dalam menciptakan stabilitas hukum untuk masa berabad-abad yang memperlihatkan melemahnya lembaga-lembaga politik Islam. Memang tidak seluruhnya dapat dihindarkan, tetapi perubahan yang benar-benar terjadi banyak berkenaan teori hukum dan suprastruktur yang sitematis daripada perubahan dalam hukum positif. Secara keseluruhan, hukum Islam membias sesuai dengan kondisi sosial dan ekonomi pada periode awal kekuasaan 
'Abbasiyah, tetapi hukum itu akhirnya berkembang semakin jauh dari sentuhan perkembangan kenegaraan dan kemasyarakatan yang kemudian.

Semestinya, proses historis pembentukan hukum Islam tersebut tidak bisa dipisahkan dari sejarah umat Islam itu sendiri, khususnya sejarah perpolitikan. Karena ketika pemerintahan Islam berkuasa, hukum Islam merupakan hukum yang berlaku di daerahnya kekuasaanya secara idealistis.

\section{Tanggapan Terhadap Gagasan Schacht}

Satu tanggapan terhadap gagasan Schacht tentang pembentukan hukum Islam, yaitu dari ahli sejarah hukum Inggris, Noel James Coulson. Coulson, walaupun mengakui validitas garis besar gagasan Schacht, ${ }^{48}$ menganggapnya sulit untuk memahami keterputusan (discontinuity) yang diciptakan Schacht antara al-Qur`an dengan pembentukan hukum Islam. Berbeda dengan Schacht, Coulson berpendapat bahwa legislasi al-Qur`an, khususnya aturan-aturan rinci mengenai hukum keluarga telah memunculkan perkembangan hukum secara berkesinambungan. ${ }^{49}$

Muhammad, menurut Coulson, pasti telah menghadapi berbagai persoalan hukum dan posisinya sebagai juru penengah (hakam), tidak diragukan merupakan kesinambungan dari kebiasaan pra Islam. Oleh sebab itu, dalam pandangan Coulson, tepat jika dikatakan bahwa Muhammad sendiri telah menandai permulaan perkembangan struktur hukum dari prinsip-prinsip etis yang terdapat dalam al-Qur`an.50

Selain Coulson, Azami satu-satunya sarjana yang menulis buku khusus ditujukan kepada karya Schacht, Origins. Dengan mendukung berbagai kesimpulan yang dicapai dalam buku sebelumnya, Studies in Early Hadith Literature, ia menantang gagasan Schacht termasuk tentang pembentukan hukum Islam.

Terlepas dari kritiknya yang sangat detail, Azami secara umum mengemukakan pendapat yang sama dengan pendapat para sarjana lainnya yang mengkritik Schacht karena tidak memberikan perhatian cukup kepada berbagai keputusan hukum al-Qur'an yang menurut Azami, merupakan kesalahan metodologis yang fundamental. ${ }^{51} \mathrm{Hal}$ ini benar-benar karena Schacht salah konsepsi tentang hukum dan posisi Nabi sebagai penafsir hukum Tuhan yang berdasarkan wahyu, Azami telah mengabadikan satu bab dalam karyanya, Schacht Origins ${ }^{52}$ untuk menjelaskan konsep hukum dan pernan Nabi yang berhubungan dengan hukum berdasarkan ayat-ayat al-Qur`an.

Azami kelihatannya terkejut oleh pernyataan Schacht bahwa tujuan Muhammad adalah bukan untuk menciptakan hukum baru,53 dan hukum semacam itu berada di luar wilayah agama. ${ }^{54}$ Pernyataan mengejutkan ini membuatnya merespon secara emosional dan apologetik terhadap ide Schacht dan akibatnya ia tidak menyajikan bantahan yang tegas terhadap berbagai pandangan Schacht. Sayangnya, semangatnya untuk menonal ide Schacht terkadang mengarahkannya menjadi salah menyajikan pokok pandangan Schacht. 
Hukum Islam adalah satu rangkuman yang meliputi seluruh kewajiban keagamaan, segala perintah Tuhan yang mengatur tata kehidupan setiap muslim dalam semua aspeknya yang sumbernya adalah al-Qur'an dan sunnah Nabi. Peraturan-peraturan itu terdiri dari norma-norma yang berkenaan dengan peribadatan, pengabdian, masalah politik dan aturan hukum dalam pengertian secara sempit. Pembatasan tersebut ditinjau dari segi sejarah dan sistemnya dapat dibenarkan, walaupun demikian tentu saja harus diingat bahwa membicarakan hal-hal yang berkenaan dengan hukum berarti memikirkan bagian dari sistem kaidah-kaidah etika dan agama itu sendiri.

\section{Penutup}

Gagasan utama Schacht tentang pembentukan hukum Islam, berbeda dengan pandangan tradisional. Schacht menganggap bahwa hukum Islam tidak berasal dari kehidupan Nabi Muhammad SAW., dan ia melihat bahwa praktek populer dan administrasi pemerintahan Bani Umayyah sebagai titik tolak bagi pembentukan hukum Islam.

Meskipun basis pembentukan hukum Islam telah ada sejak masa jauh sebelum masa Syafi'i, namun fakta historis yang dapat dibuktikan hanyalah karya yang disusun oleh Syafi'i. Walaupun terdapat hubungan tidak lebih dari apa yang diinformasikan Syafi'i. Sehingga kesimpulan Schacht, bahwa pembentukan hukum Islam tidak berawal sejak masa Nabi, karena tidak didukung oleh fakta-fakta historis.

Berbagai tanggapan terhadap gagasan yang dilontarkan oleh Schacht tentang pembentukan hukum Islam merupakan hasil penelitian terhadap wacana-wacana ilmiah yang berkembang. Suatu penelitian memiliki metodologi yang valid untuk mencapai hasil yang dapat diuji kebenaran ilmiahnya. Perbedaan metodologi sangat memungkinkan akan menghasilkan kesimpulan yang berbeda pula.

\section{Catatan Akhir}

${ }^{1}$ Joseph Schacht, "Theology and Law in Islam," dalam G.E. von Grunebaum (Ed.), Theology and Law in Islam, (Weisbaden: Otto Harrasowitz, 1971), hlm. 23

2 Joseph Schacht, An Introduction to Islamic Law, (Oxford: The Clorendon Press, 1965), hlm. 1

${ }^{3}$ Robert Brunschvig, Joseph Schacht (1902-1969," Studia Islamica 31 (1970), hlm. v.

4 George F. Hourani, "Joseph Schacht, 1902-1969," Journal of American Oriental Society 90 (1970), hlm. 163

${ }^{5}$ Aharon Layish, "Notes on Joseph Schacht's Contribution to Studi of Islamic Law," British Society for Middle Eastern Studies, Bulletin 9 (1982), hlm. 132

${ }^{6}$ Hourani, loc.cit.

${ }^{7}$ Ibid., hlm. 164

8 Ibid.

9 G.E. von Grunebaum (Ed.), Theology and Law in Islam, (Weisbaden: Otto Harrasowitz), hlm. 190

${ }^{10} \mathrm{Ibid}$. 
${ }^{11}$ Hourani, op.cit., hlm. 165

12 Ibid., hlm. 166

${ }^{13}$ G.E. von Grunebaum, loc.cit

14 Joseph Schacht, The Origins of Muhammadan Jurisprudence, (Oxford: The Clarendon Press, 1967), hlm. 133.

15 Schacht, An Introduction..., op.cit., hlm. 19.

16 Schacht, The Origins..., op.cit., hlm. 190.

17 'Umar Sulaiman al-Asyqar, Tarikh al-Figh al-Islami, (Amman: Dar al-Nafa'is, 1991), hlm. 81

18 Schacht, The Origins..., op.cit., hlm. 29, 76, 87, 105, 133, 233, 276.

19 Schacht, An Introduction..., op.cit., hlm. 17.

${ }^{20}$ Ibid., hlm. 8.

21 Ibid., hlm. 15-16.

22 Ibid., hlm. 25.

23 Schacht, The Origins..., op.cit., hlm. 283.

24 Ibid., hlm. 26.

25 Ibid., hlm. 7.

${ }^{26}$ Schacht, An Introduction..., op.cit., hlm. 28.

27 Schacht, The Origins..., op.cit., hlm. 98.

28 Ibid., hlm. 10.

29 Aliran ini didirikan oleh Abu Hanifah, yang nama lengkapnya adalah Nu'man ibn Tsabit ibn Zauthi. Secara politik, Abu Hanifah hidup dalam dua generasi. Ia dilahirkan di Kufah pada tahun $80 \mathrm{H}$, artinya ia lahir pada zaman Dinasti Umayyah, tepatnya pada zaman kekuasaan 'Abd al-Malik ibn Marwan. Lihat Manna' al-Qaththan, Al-Tasyri' wa al-Fiqh al-Islami: Tarikhan wa Minhajan, (Mesir: Dar al-Ma'arif, 1989), hlm. 202. Beliau meninggal pada zaman kekuasaan Dinasti 'Abbasiyah, yaitu pada masa pemerintahan al-Manshur. Ia hidup selama 52 tahun pada zaman Umayyah dan 18 tahun pada zaman 'Abbasiyah. Lihat Ahmad Amin, Dhuha al-Islam, Nasy ah al-'Ulum fi al-'Ashr al-'Abbasi al-Awwal, (Mesir: Maktabah al-Nahdhah al-Mishriyah, 1974), hlm. 177.

30 Malikiyah adalah aliran hukum Islam yang didirikan oleh Imam Malik, yang nama lengkapnya adalah Malik ibn Anas ibn Abi 'Amir al-Ashbahi. Ia dilahirkan di Madinah pada tahun $93 \mathrm{H}$. tidak berbeda dengan Abu Hanifah, beliau juga termasuk ulama dua zaman. Ia lahir pada zaman Bani Umayyah, tepatnya pada zaman pemerintahan al-Walid ibn 'Abd al-Malik, dan meninggal pada zaman Bani 'Abbas, tepatnya pada zaman Harun al-Rasyid, tahun $179 \mathrm{H}$. Ia sempat merasakan pemerintahan Umayyah selama 40 tahun dan masa pemerintahan Bani 'Abbas selama 46 tahun. Lihat Muhammad 'Ali al-Sayis, Tarikh al-Figh al-Islami, (Beirut: Dar al-Kutub al-'Ilmiyah, 1990), hlm. 111-112.

31 Schacht, An Introduction..., op.cit., hlm. 59.

32 Schacht, The Origins..., op.cit., hlm. 128-129.

33 Nama lengkapnya adalah Ahmad ibn Hanbal ibn Asad ibn Idris ibn 'Abdullah ibn Hasan al-Syaibani, lahir di kota Salam Baghdad bulan Rabi'al-Awwal tahun $164 \mathrm{H}$ dan wafat di Baghdad tahun $231 \mathrm{H}$. Lihat Muhammad Abu Zahrah, Ibn Hanbal: Hayatuhu wa 'Ashruhu wa Fiqhuhu, (Mesir: Dar al-Fikr al-'Arabi, 1941), hlm. 16-17.

34 Schacht, An Introduction..., op.cit., hlm. 62-63. Schacht juga menyebut guru-guru pribadi lainnya, seperti Abu Yusuf, Syaibani, Sufyan Tsauri, Auza'i, Ibn Taimiyah dan Ibn Qayyin al-Jauziyah. Mengenai aliran hukum, Schacht menulis, terdapat beberapa aliran hukum lainnya, khususnya periode awal. Namun sejak sekitar tahun $1300 \mathrm{M}$. hanya empat aliran hukum yang masih hidup dalam ortodoksi Islam, yakni aliran Hanafi, Maliki, Syafi'i, dan Hanbali. 
Al-Fikra: Jurnal Ilmiah Keislaman, Vol. 4, No. 2, Juli-Desember 2005

35 Schacht, An Introduction..., op.cit., hlm. 26, 27, 29. Lihat juga The Origins..., op.cit., hlm. 283

${ }^{36}$ Schacht, An Introduction..., op.cit., hlm. 45

${ }^{37}$ Abu Hamid al-Ghazali, Al-Mustashfa min 'Ilm al-Ushul, (Mesir: Mushthafa Babi alHalabi, 1971), hlm. 119

38 Schacht, An Introduction..., op.cit., hlm. 46

${ }^{39}$ Muhammad ibn Idris al-Syafi'i, Al-Risalah, (Beirut: Dar al-Fikr, t.th.), hlm. 22

${ }^{40}$ Schacht, The Origins..., op.cit., hlm. 88-94

${ }^{41}$ Al-Syafi'i, op.cit., hlm. 457. dalam pandangan Schacht, konsep ijma' semacam itu didasarkan atas gagasan yang diformulasikan sesaat sebelum Syafi'i bahwa segala sesuatu yang disetujui atau yang tidak disetujui oleh orang muslim itu baik atau buruk dalam pandangan Allah, dan hanya pada pertengahan abad ketiga hijrah, kata Schacht, gagasan itu dikembangkan dan dimasukkan ke dalam bentuk hadis dari Nabi: "Umatku tidak akan sepakat atas kesalahan." Lihat Schacht, An Introduction ..., op.cit., hlm. 47

42 Al-Syafi'i, op.cit., hlm. 476. Untuk mengetahui sikap Syafi'i terhadap ra`yu, istihsan, istishhab, dan konsepnya tentang qiyas dan ijtihad, lihat The Origins..., op.cit., hlm. $120-128$

${ }^{43}$ Ibid., hlm. 137

${ }^{44}$ Ibid.

${ }^{45}$ Schacht, An Introduction..., op.cit., hlm. 70

${ }^{46}$ Ibid., hlm. 70-71

${ }^{47}$ Ibid., hlm. 72

${ }^{48}$ Noel J. Coulson, The History of Islamic Law, (Edinburg: Edinburg University Press, 1990), hlm. 4 dan 64.

${ }^{49}$ Ibid., hlm. 64-65

${ }^{50} \mathrm{Ibid} ., \mathrm{hlm} .22$

51 Muhammad Mushthafa 'Azami, On Schacht's Origins of Mohammadan Jurisprudence, (Riyadh: King Saud University Press, 1985

52 Ibid., hlm. 5-18

${ }^{33}$ Schacht, An Introduction..., op.cit., hlm. 11

${ }^{54} \mathrm{Ibid} .$, hlm. 19. Lihat pula The Origins..., op.cit., hlm. v 